DOI 10.26886/2414-634X.6(25)2018.11

UDC: 792 / 796.4

\title{
SPECIFIC FEATURES OF THE SCENIC METHOD IN THE GENRE "CIRCUS GYMNASTICS": FORMAL TECHNICAL CHARACTERISTICS, AS WELL AS ANALYSIS OF TRICKS ON "SHVUNG TRAPE" (TRAPEZIUM)
}

\author{
Anatoly Stetsenko, Associate professor \\ Svetlana Dobrovolskaya, Associate professor \\ Kyiv Municipal Academy of Variety and Circus Art, Kyiv, Ukraine
}

The article discusses the features of the stage method in accordance with the genre of "Circus gymnastics" in the context of art education of the circus movement. Considering the terminological characteristics of individual concepts in gymnastics, understand their specificity. Elements of work in aerial gymnastics on a trapeze are described. Certain features of individual exercises and elements on the trapezoid.

Keywords: circus art, circus genre, gymnastics, circus gymnastics, scenic method.

Анатолий Стеценко, Светлана Добровольская, доценты кафредры цирковых жанров, заслуженные артисты Украины. Специярические особенности в сценическом методе жанра "Цирковая гимнастика»: фрормально-технические характеристики, а также анализ работы воздушной гимнастики на трапеции / Киевская муниципальная академия эстрадного и циркового искусств, Украина, Киев.

В статье рассмотрены особенности сценического метода по жанру «Цирковая гимнастика», в контексте художественного образования циркового направления. Даны терминологические характеристики отдельных понятий по гимнастике, для понимания их специфрики. Описаны элементы работы в воздушной гимнастике на трапеции. Уточнены особенности выполнения отдельных упражнений и элементов на трапеции.

Ключевые слова: цирковое искусство, цирковой жанр, гимнастика, цирковая гимнастика, сценический метод.

\section{Formulation of the problem}

For the first time in a study on circus gymnastics in art criticism of the circus movement, the theory and practice of air gymnastics on a trapeze is analyzed.

The purpose of the article of the study is to define the conceptualcategorical and terminological features of circus gymnastics, as well as to analyze the stage method of training, students of the higher school for 
studying the elements of aerial gymnastics on a trapezoid in the context of the educational process at the Kiev Municipal Academy of Variety and Circus Arts.

\section{Analysis of research}

Such studies in the field of circus criticism as well as gymnastic pedagogy were conducted by such professional pedagogues and researchers as Antonov Ghenadiy, Afanasyev Yury, Belokhvostov Boris [2], Kashevarov Vladimir, Kozhevnikov Sergei [4]. Their research concerned art methodology for acrobatics, scenic and technical props for circus acrobats on the arena and under the dome, as well as the processes of aesthetic realization of the artistic image in circus criticism.

\section{Statement of the main material}

Gymnastics is a circus and sports genre, the essence of which is to demonstrate in technical and artistic form the achievements of the physical development of the human body. It uses gymnastic apparatus used in the circus. Circus (air) gymnastics includes exercises performed on projectiles or apparatus suspended from the circus dome: shvung trape, gymnastics on the cord de volane, on the cord-de-parel gymnastics; gymnastics on the canvases; gymnastics on belts; gymnastics on the horizontal bars; gymnastics on bamboo.

Bamboo is a type of circus (aerial) gymnastics. Gymnastic equipment, which is a metal pole, 3-4 meters long, which is hung vertically, on which exercises are performed by two gymnasts.

Cord de Volan - a kind of circus (aerial) gymnastics. Gymnastic equipment - a thick rope that hangs horizontally at both ends so that a sag is formed, in the middle of which the actor performs the exercises both on the spot and in swinging.

Cord de Parel is a type of circus (aerial) gymnastics. An airgymnastic apparatus is a tightly stretched vertical rope, on which an artist performs tricks similar to exercises in the first or bamboo ("flag", blanche", "somersault"). The upper end is attached to the dome; lower pulls the assistant; top provided with loops. The number that is shown on the cordde-parille is performed by one performer or steam.

Trapeze (shvung trape) - a kind of circus (air) gymnastics. Gymnastic projectile - a metal crossbar, which is suspended horizontally on two ropes (with a rope inside) attached to it at the edges. Exercises are performed in the air and in the support both on a stationary and on a swaying trapezium [6, p. 10-12].

The main objectives of the study of discipline Specialization by genre (Air gymnastics-trapezoid) are:

- study of the main types of mobile actions. The ability to perform them in various conditions on the complexity of gymnastic equipment;

- development of the necessary moving qualities: flexibility, strength, agility, vestibular apparatus; 
- the formation of sustainable motor skills in gymnastic exercises for the subsequent work on complex stunts, to process the skills and abilities to independently perform gymnastic exercises, foster a steady interest in the genre, help develop creative thinking, artistry, and a conscious attitude to the creative process;

- the formation of basic mobile actions on gymnastic equipment, which positively affect the diverse development of students, helps to identify individual opportunities in the genre;

- further improvement of the technical means of performing artistic combinations and graduation numbers;

- education in a circus gymnast of high moral and volitional qualities, sustainable psychological training, the formation of special organizational skills in solving creative problems [4, p. 29].

\section{Basic skills.}

The student should be able to:

- Possess effective methods of maintaining body balance.

- Properly warm up with the inclusion of simple exercises.

- Apply safety equipment correctly, both when learning and while performing gymnastic elements and exercises. exercises.

- Properly perform both simple and complex gymnastic elements and

- Correctly analyze your own technique of performing gymnastic elements and exercises, be able to find and correct technical errors in time.

- On the basis of the mastered gymnastics program material, be able to correctly compose and perform simple and strengthened gymnastic combinations.

Group exercises in gymnastics, in turn, provide comprehensive physical development based on and in organic connection with the requirements and norms of training circus artists of various genres, and provide an opportunity to improve the skills of circus performers in general [5, p. 120-123].

Theme 1. Trapezium (in place).

With waving in the hang, pushing with two legs in the hang, bent over, go to the hang, bent. Hang on bent legs, bend over. Up forward climb Pulling up, stand on the trapeze, straightening your arms, standing tall and back to the starting position. Hang on bent legs with a grip on a trapeze and sticking with both feet into the height. Fly back dismount.

Theme 2. Waving in the hang.

Swinging in hanging on bent legs. Rise from a hanging in an emphasis the stroke and force. From a standing position on the trapezoid roll forward to the rear. With weight lifting in a stop with a coup, dismount.

Theme 3. Swinging in hanging on bent legs. 
With swinging in the vise, lifting the coup point-blank. Circle forward to VIS, swoop forward, with two legs sticking out, VIS on bent legs.

With a jack forward, climb into the saddle and, pulling up to move to the standing position on the trapezium.

Flip forward into the trapezium. Hang on bent legs, pushing with two legs or hanging on bent legs with a transition to hanging with straight legs. With a weight angle, unbending back, dismount.

Theme 4. With the weight of the coup point-blank (group of girls). High behind, lowering one of the hands, turning around, hanging on one hand. The rise of the coup point-blank. Standing on a trapeze, pulling up with a grip on the ropes, he hung, bent, hung, legs arched. Standing on the trapezoid, roll forward.

Theme 5. Pulling on the ropes, stand on the trapeze. somersault forward to the top and to the top.

With waving in the vise, pushing with two legs, in the height behind the one hand and height.

Having put two feet, hanging on bent legs and swinging. Makhom forward climb into the saddle and, catching up to get on the trapezoid. Pulling up on the ropes, bent over, hanging, bent over and forcefully to stand on the trapeze. Flip forward to the top and to the hang on bent legs, pushing with two feet into the height. Fly back dismount [3, p. 78].

Theme 6. Lifting and coups on trapeze without.

The rise of a coup with force and a swing from the wall, bent over the rise in the middle of the bend. Turns in a vise with an emphasis force, swaying in Sit and standing.

Theme 7. With waving rise to support and balance lying.

With swinging, lifting with a turn-up and balance, lying down. Turn forward and swoop forward, pushing with two legs, high bent. Hang on the right hand and the toe of the left foot face up, turn round face down ("flag"). He hangs on his bent arms, swings forward into the saddle and, pulling himself up onto the trapeze. Lowering the left and right hands, turn around and back to the starting position. Flip forward into the seat and in the vis on the bent arms, pushing with two feet into the height. Angle in the hang and unbend.

Theme 8. From sit openness in socks.

The rise of the coup in the emphasis by force and swoop down from hanging out, bent over, the rise in the middle by unbending and strength, from the edge of the socks.

Theme 9. Pumps forward to the seat and from the seat with a break in the socks in a stroke forward to hanging, waving in hanging.

With swinging on bent legs swoop forward hanging on by the grip on the rope under the trapezoid and somersaults back to the flag socks. 
Theme 10. Breakage in socks with a sit on a trapeze and off balance on lower back.

From the side, there is a break in the socks, from oneself on the lower back, a break in the socks, swaying in the neck (one of the most complicated in terms of the technique of execution is the kind of swaying). Breakage in socks with a sit on a trapeze and off balance on the lower back. Swaying in the wall.

\section{Conclusions}

Thus, the terminological characteristics of circus gymnastics are specified, as well as the analysis of the formal technical characteristics and characteristics of the trapezium elements. The principles of work with students in aerial gymnastics on a trapeze are specified. Accuracy and quality of performance of tricks and trapeze exercises lead to a high level and competitiveness of graduates Kiev Municipal Academy of Variety and Circus Arts.

\section{Literature:}

1. Акробатика: программа для училищ циркового и эстрадного искусства по специальности № 2109 «Цирковое искусство» (отделение циркових жанров). - М.: ВМУЗИК, 1980. - 36 с.

2. Белохвостов Б. Н. Вольтижная акробатика / Б. Н. Белохвостов. М.: ЛКИ 2012. - 304 c.

3. Запашный В.М. Вольтижная акробатика / В. М. Запашный. М. Искусство, 1961. - $131 \mathrm{c}$.

4. Кожевников С. В. Акробатика: учеб. пособие для училищ циркового искусства / С. В. Кожевников. - М.: Искусство, 1984. Изд. 3-е. доп. 222 c. : puc.

5. Orel Dmytriy. The specificity of "Circus Gymnastics on the Canvases" in teaching and the creative process of the Kyiv City Academy Variety and Circus Arts. Paradigme of knowledge. - Section "Art". - Muscat, Oman: Center for International cooperation TK "Meganom". - 2017. - № 5 (25). P. 120-123.

6. Орел Дмитро. Кашеваров Володимир. Сценічно-технічна підготовка в циркових жанрах: техніка безпеки, манеж, реквізит: навчальний посібник / Д. В. Орел. - К.: КМАЕЦМ, 2018. - 75 с.: іл.

\section{References:}

1. Acrobatic: a program for circus and variety art schools on specialty No. 2109 "Circus Art" (department of circus genres). - M.: VMUZIK, 1980. - 36 p.

2. Belokhvostov Boris. Voltige acrobatics / Boris Belokhvostov. - M.: LKI 2012. $-304 p$.

3. Zapashnyj V. Voltige acrobatics / V. Zapashnyj. - M.: Iskusstvo, 1961. $131 p$. 
4. Кожевников Сергей. Acrobatics: a textbook. manual for schools of circus art / C. Кожевников. - M. : Iskusstvo, 1984. Izd. 3-e. dop. - 222 p.: ris.

5. Orel Dmytriy. The specificity of "Circus Gymnastics on the Canvases" in teaching and the creative process of the Kyiv City Academy Variety and Circus Arts. Paradigme of knowledge. - Section "Art". - Muscat, Oman: Center for International cooperation TK "Meganom". - 2017. - № 5 (25). P. 120-123.

6. Orel Dmytriy. Kashevarov Volodymir. Stage-technical training in circus genres: safety engineering, playpen, props / Dmytriy Orel. - K.: KMAVC, 2018. - 75 p.: il. 